\title{
High-altitude pulmonary oedema in native highlanders
}

\author{
Uday Yanamandra, ${ }_{1}^{1}$ Sagarika Patyal, ${ }^{2}$ Ruchira Mukherji, ${ }^{3}$ Velu Nair ${ }^{4}$
}

${ }^{1}$ Dept of Internal medicine, 153 General Hospital, Leh, Jammu \& Kashmir, India ${ }^{2}$ Department of Opthalmology, 153 General Hospital, Leh, Jammu and Kashmir, India ${ }^{3}$ Department of Emergency Medicine, 153 General Hospital, Leh, Jammu and Kashmir, India

${ }^{4}$ Armed Forces Medical College, Pune, Maharashtra, India

\section{Correspondence to} Dr Uday Yanamandra, udayj2@gmail.com

\section{CrossMark}

To cite: Yanamandra $U$, Patyal S, Mukherji R, et al. BMJ Case Rep Published online: [please include Day Month Year] doi:10.1136/ bcr-2013-202513

\section{DESCRIPTION}

A 28-year-old Ladakhi police personnel, native highlander, serving at high altitude $(\sim 12000 \mathrm{ft})$ presented with a short history of cough and breathlessness while on leave for 10 days at the same altitude. There was no history of deinduction to lower altitudes in the past 10 years. Symptoms were preceded by a history of unaccustomed exertion (farming). There was no associated history of fever, expectoration and chest pain with the above symptoms or any past cardiopulmonary comorbidity.

On examination, the mesomorphic man (height $162 \mathrm{~cm}$ and weight $58 \mathrm{~kg}$ ) was tachypnoeic with coarse crepitations on the right hemithorax. His peripheral saturation was $74 \%$ in ambient air. Chest X-ray (CXR (07/10/13 showed a non-homogenous opacity suggestive of lobar consolidation in right upper zone (RUZ) with interlobar fissural oedema (figure 1). All haematological and biochemical parameters were normal with fibrin degradation products (FDP) and D-dimer being negative.

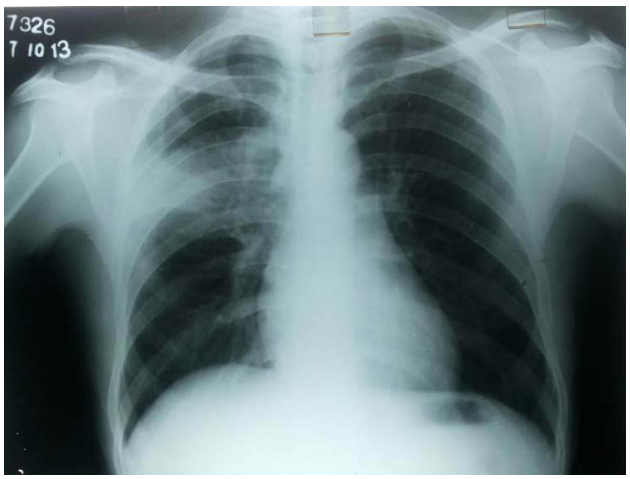

Figure 1 Chest X-ray of a case of high-altitude pulmonary oedema on the day of admission showing non-homogenous opacity suggestive of lobar consolidation in RUZ with interlobar fissural oedema.

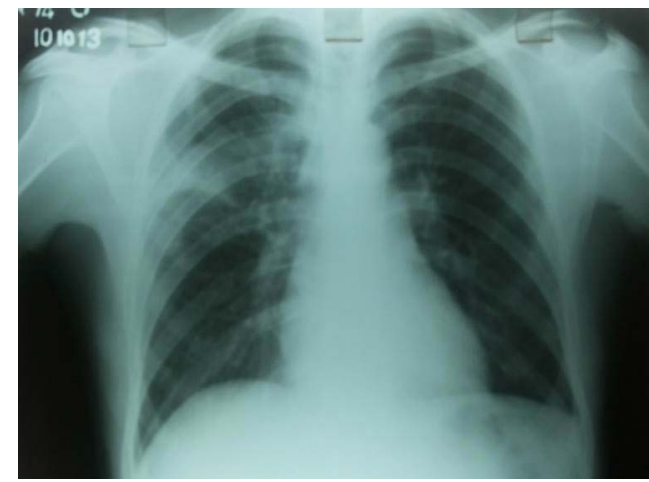

Figure 2 Chest X-ray on day 3 of admission showing resolution of opacities compared with previous $X$-rays.
The patient was managed only with oxygen therapy, ${ }^{1}$ considering a possibility of high-altitude pulmonary oedema (HAPO). The patient's clinical condition returned to normalcy by day 3 (D3). His serial CXR showed a progressive resolution (figures 2 and 3) of opacity characteristic of HAPO with D7 CXR being normal (figure 4).

The radiological opacities in pneumonitis resolve on antibiotic treatment in $2-6$ weeks, ${ }^{2}$ whereas in our case, opacities started resolving by D3 as commonly seen in HAPO. ${ }^{3}$ Important differentials for a patient with breathlessness, tachypnoea and cough in high altitude include HAPO, pulmonary thromboembolism and pneumonitis. The other differentials were carefully excluded in this case.

This image demonstrates the likelihood of the development of HAPO in a well-adapted native highlander on unaccustomed strenuous exertion in high-altitude area. This image also signifies varied radiological manifestations of HAPO aping pneumonic consolidation.

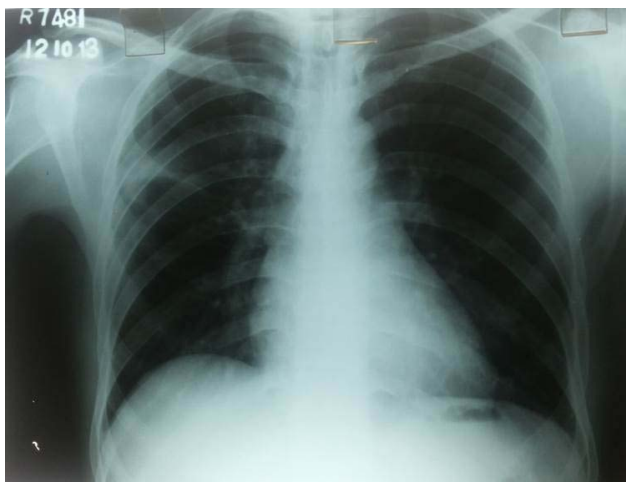

Figure 3 Chest X-ray on day 5 of admission showing resolution of opacities compared with previous X-rays.

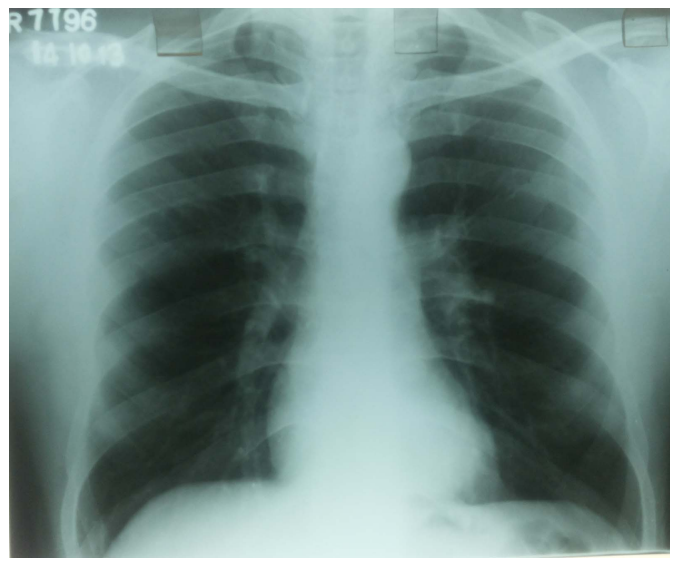

Figure 4 Chest X-ray on day 7 of admission showing a complete resolution of opacities. 


\section{Learning points}

- Native highlanders are not immune to the development of high-altitude pulmonary oedema (HAPO).

- It is not the duration of stay but the unaccustomed exertion which is crucial in determining the susceptibility to HAPO.

- Radiological presentation of HAPO can masquerade as lobar pneumonic consolidation and pulmonary thromboembolism's wedge opacities which are important differentials.

Acknowledgements The authors would like to acknowledge the o/o DGAFMS for providing support and infrastructure in the management of the high-altitude illnesses in the remotest parts of the world.
Contributors UY and RM were actively involved in management of the case. All authors contributed to the manuscript preparation and follow-up of the patient.

Competing interests None.

Patient consent Obtained.

Provenance and peer review Not commissioned; externally peer reviewed.

\section{REFERENCES}

1 Luks AM, McIntosh SE, Grissom SE, et al. Wilderness medical society consensus guidelines for the prevention and treatment of acute altitude illness. Wilderness Environ Med 2010;21:146-55.

2 Mittl RL Jr, Schwab RJ, Duchin JS, et al. Radiographic resolution of community acquired pneumonia. Am J Respir Crit Care Med 1994;149:630-5.

3 Vock P, Brutsche MH, Nanzer A, et al. Variable radiomorphological data of high altitude pulmonary oedema. Features from 60 patients. Chest 1991;100:1306-11.

Copyright 2014 BMJ Publishing Group. All rights reserved. For permission to reuse any of this content visit http://group.bmj.com/group/rights-licensing/permissions.

BMJ Case Report Fellows may re-use this article for personal use and teaching without any further permission.

Become a Fellow of BMJ Case Reports today and you can:

- Submit as many cases as you like

- Enjoy fast sympathetic peer review and rapid publication of accepted articles

- Access all the published articles

- Re-use any of the published material for personal use and teaching without further permission

For information on Institutional Fellowships contact consortiasales@bmjgroup.com

Visit casereports.bmj.com for more articles like this and to become a Fellow 